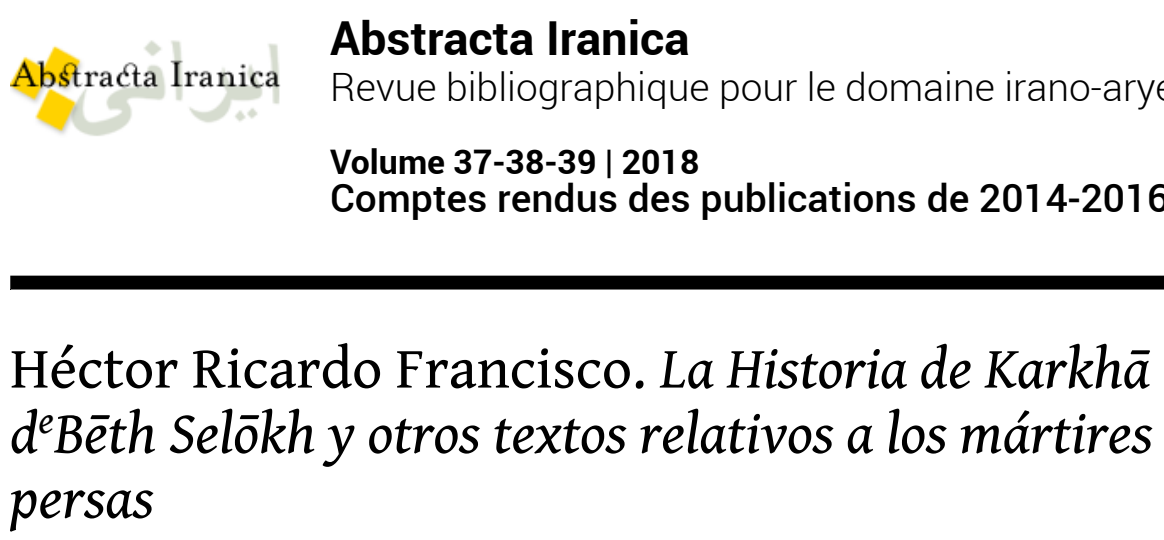

Christelle Jullien

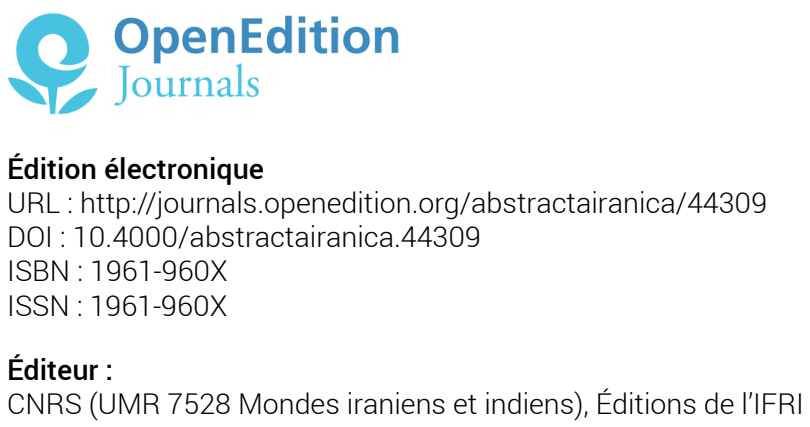

Référence électronique

Christelle Jullien, « Héctor Ricardo Francisco. La Historia de Karkhā dBēth Selōkh y otros textos relativos a los mártires persas », Abstracta Iranica [En ligne], Volume 37-38-39 | 2018, document 15, mis en ligne le 30 décembre 2018, consulté le 27 septembre 2020. URL : http://journals.openedition.org/ abstractairanica/44309 ; DOI : https://doi.org/10.4000/abstractairanica.44309

Ce document a été généré automatiquement le 27 septembre 2020.

Tous droits réservés 


\title{
Héctor Ricardo Francisco. La Historia de Karkhā d'Bēth Selōkh y otros textos relativos a los mártires persas
}

\author{
Christelle Jullien
}

\section{RÉFÉRENCE}

Héctor Ricardo Francisco. La Historia de Karkhā deBēth Selōkh y otros textos relativos a los mártires persas. (Byzantina \& Orientalia Studia 3), Buenos Aires : Instituto Multidisciplinario de Historia y Ciencias Humanas, 2016.

1 Signalons ce travail soigné de traduction et d'édition d'un choix de plusieurs textes en syriaque, annotés et commentés, en langue espagnole. Il s'agit de la première version réalisée ce jour de l'Histoire de Karkā deB Bēth-Slokh, du VI ${ }^{\mathrm{e}}$ siècle, qui relate la passion de chrétiens du Bēth-Garmaï, à l'est du fleuve Tigre, sous le roi sassanide Yazdgird II. L'ouvrage est consultable en ligne. Une version française par M. Debié et alii devrait paraître dans la collection des Sources chrétiennes. La Historia s'ouvre par une étude préliminaire de mise en contexte sommaire sur l'Église en monde iranien, puis se focalise très brièvement sur le diocèse du Bēth-Garmaï, théâtre des événements de la narration. La seconde partie est dévolue au texte proprement dit; la traduction est précédée d'une introduction sur les manuscrits et les sources de l'hagiographe, le contexte littéraire, fournissant aussi un résumé des principales passions antérieures. Dans une troisième partie sont regroupés différents textes martyrologiques considérés par l'A. comme " complémentaires » au document principal ici à l'étude - des textes connus déjà publiés: les Actes de Mār Māri, le martyre de Narse(h), des chrétiens du Bēth-Garmaï, et celui de šābuhr. Enfin un hymne consacré à Tahm-Yazdgird (personnage de l'Histoire de Karkā) par Georges Warda (XIII ${ }^{\mathrm{e}}$ s.) vient accompagner l'ensemble. Une bibliographie et un index onomastique terminent ce petit ouvrage qui 
a par ailleurs le mérite de faire connaître les actes des martyrs perses de l'époque sassanide en milieu hispanophone.

\section{AUTEURS}

\section{CHRISTELLE JULLIEN}

CNRS, Mondes iranien et indien, Paris 